\title{
New and interesting species of Chrysobalanaceae
}

\author{
Ghillean T. Prance $\left({ }^{*}\right)$
}

\begin{abstract}
Four new species of Licania and two of Hirtella are described and additional notes are given on three other little known species of Chrysobalanaceae. All the new species have been collected recently since 1972 when the author monographed the neotropical Chrysobalanaceae. Three of the new species are from Amazonia, two from Panama, and one from Pacific coastal Colombia confirming that these three areas still have many undescribed species and are in need of further exploration.
\end{abstract}

\section{INTRODUCTION}

Since my monograph of the Chrysobalanaceae, in 1972 (Prance, 1972) many new species of Chrysobalanaceae have been discovered. Twenty new species have been described in Lundell (1974) and Prance (1973, 1974a, 1974b, 1976, 1977, 1978 in press). The quantity of new material still being discovered from many parts of the neotropics indicates that there is still much exploration to be done. The present paper presents another six new species all based on material collected between 1972 and 1976 that have been sent to me for identifification. Table 1 gives a summary of all additions to the neotropical Chrysobalanaceae since the 1972 monograph.

\section{Licania Aublet}

1. Licania cuatrecasasii Prance, sp. nov. (Fig. 1)

Licania ab subgenero Moquilea sectio Leptobalanus pertinens. Ab L. apetala ( $E$. Mey.) Fritsch et L. sparsipilis Blake foliis dense brunneo-lanato-pubescentibus, venis subtus profunde reticulatis, apicibus cuspidatis, petiolis longioribus usque ad $11 \mathrm{~mm}$ longis eglandulosis; inflorescentibus brunneotomentosis; receptaculis late campanulatis diffêrt.
Tree to $30 \mathrm{~m}$ tall, the young branches puberuious soon becoming glabrous. Leaves with laminas elliptic, coriaceous, $8-12.5 \mathrm{~cm}$ long, $3-5.8 \mathrm{~cm}$ broad, cuspidate at apex, the acumen 10-15 mm long, slightly curved, subcuneate at base, glabrous above, with a compact brown lanate pubescence beneath; primary veins $10-12$ pairs, prominent beneath, prominulous above; midrib prominent on both surfaces; petioles $8-11 \mathrm{~mm}$ long, tomentellous when young, terete or slightly canaliculate, eglandular, transversely rugulose. Stipules caducous (no seen). Inflorescences of racemose panicles usually once branched with occasionally secondary branches to $10 \mathrm{~cm}$ long. the rachis and branches brow tomentellous. Flowers $\pm 2.5 \mathrm{~mm}$ long, sessile on primary and secondary branches of inflorescence. Bracts and bracteoles ovate, ca $1 \mathrm{~mm}$ long. persistent, tomentellous on exterior, entire, eglandular. Receptacle broadly campanulate, tomentose on exterior, pilose within. Calyx lobes acute, tomentellous on exterior, puberulous within. Petals absent. Stamens 10-12, inserted in a complete circle; filaments far exceeding calyx lobes, free to base, glabrous. Ovary inserted at base of receptacle villous around base, but glabrous above. Style glabrous, equalling filaments in length. Fruit not seen (25-30 $\mathrm{mm}$ according to field notes).

TYPE: Colombia. Valle, Alto Yunda, Rio Anchicaya, $1000 \mathrm{~m}$ alt., fl Oct 1972, S. Hilty 0-1 (Holotype, US; Isotype, NY).

The field notes observe that it flowers in October and the fruits mature in March-June. It is an uncommon tree in the type locality.

Licania cuatrecasasii belongs to subgenus Moquilea, section Leptobalanus. This species from the highlands of Valle comes from an area in need of further exploration. It is most closely related to $L$. apetala and $L$. sparsipilis Blake, but differs from both species in the dense lanate-brown pubescence of the leaf

(") - The New York Botanical Garden, Bronx, New York 10158, U.S.A. 

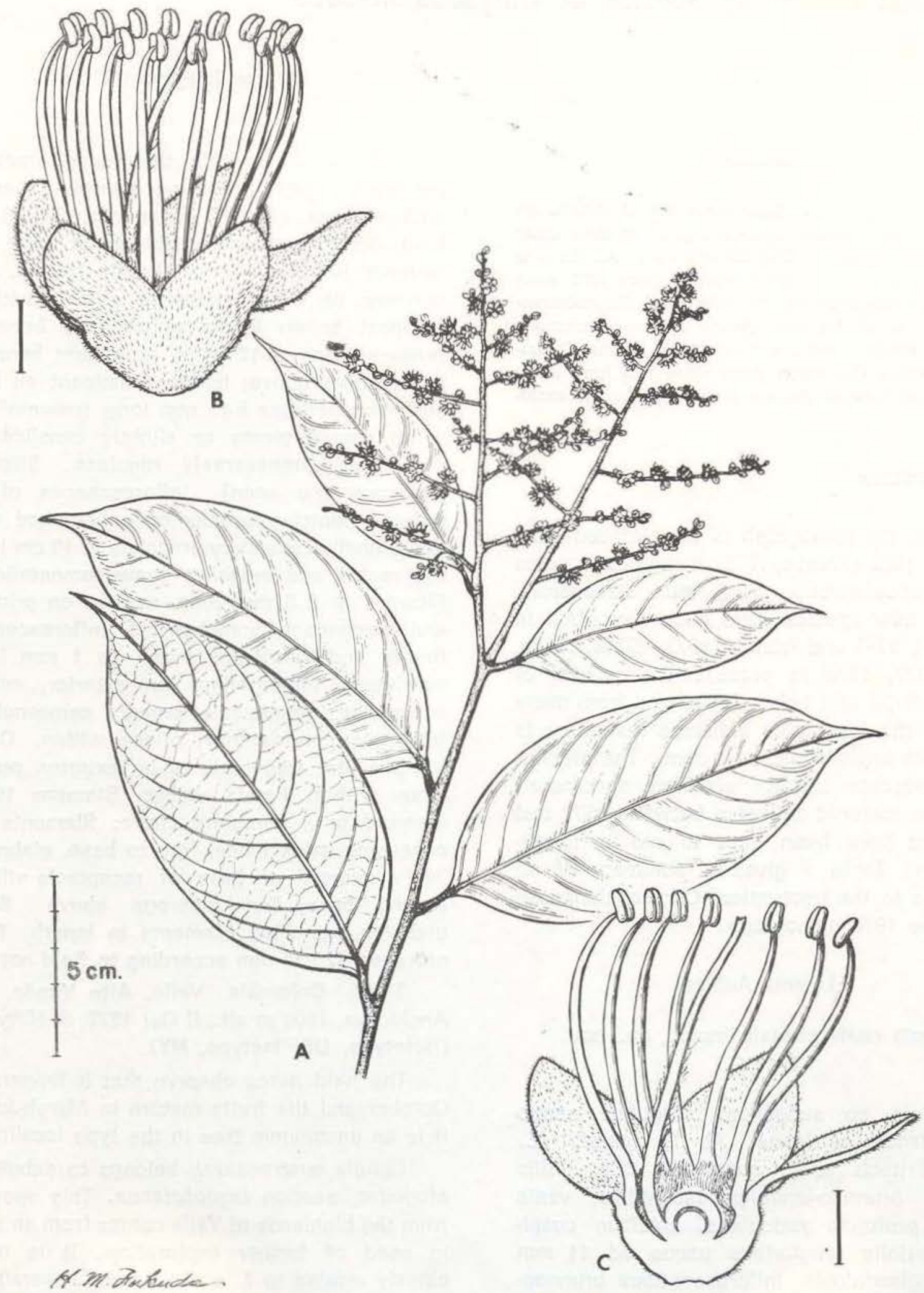

Fig. 1. Licania cuatrecasasii Prance (Hilty 0-1): A, habit; B, flower; C, flower section. 
TABLE 1. New Species of Neotropical Chrysobalanaceae described since monograph (Prance, 1972)

a. species prior to the present publication

Couєpia dolichopoda Prance (1974b)

C. edulis (Prance) Prance (1974a, 1975)

C. marlenei Prance (1974a)

Hirtella arenosa Prance (1976)

H. conduplicata Prance (1976)

Licania aracaensis Prance (1976)

L. cabrerae Prance (1976)

L. cecidiophora Prance (1978)

L. chiriquensis Prance (1977)

L. furfuracea Prance (1076)

L. guatemalensis Lundell (1974)

L. jefensis Prance (1976)

L. jimenezii Prance (1973)

L. marlenei Prance (1976)

L. mexicana Lundell (1974)

L. montana Prance (1976)

L. morii Prance (1976)

L. pakaraimensis Prance (1976)

L. stewardii Prance (1976)

L. sp. nov. (in press)

$\begin{array}{lc}\text { Locality } & \begin{array}{c}\text { collection } \\ \text { Peru : Loreto }\end{array} \\ \text { Brazil : Amazonas } & 1972 \\ \text { Brazil : Amazonas } & 1972 \\ \text { Brazil : Amazonas } & 1968 \\ \text { Brazil: Amazonas } & 1973 \\ \text { Brazil : Amazonas } & 1975 \\ \text { Colombia : Antioquia } & 1957 \\ \text { Peru : Amazonas } & 1974 \\ \text { Panama : Chiriquí } & 1975 \\ \text { Venezuela : Bolivar } & 1975 \\ \text { Guatemala } & 1971 \\ \text { Panama } & 1969 \\ \text { Suriname } & 1971 \\ \text { Brazil : Amazonas } & 1972 \\ \text { Mexico : Sinaloa } & 1943 \\ \text { Venezuela : Lara } & 1975 \\ \text { Panama } & 1975 \\ \text { Venezuela : Bolivar } & 1973 \\ \text { Brazil : Amazonas } & 1974 \\ \text { Ecuador : Napo } & 1969\end{array}$

b. species in the present publication

Hirtella magnifolia Prance

Hirtella revillae Prance

Licania cuatrecasasii Prance

L. fasciculata Prance

L. joseramosii Prance

L. kallunki Prance

$\begin{array}{ll}\text { Brazil : Amazonas } & 1976 \\ \text { Peru : Loreto } & 1975 \\ \text { Colombia : Valle } & 1972 \\ \text { Panama } & 1972 \\ \text { Brazil : Amazonas } & 1976 \\ \text { Panama } & 1975\end{array}$

Tree $12 \mathrm{~m}$ tall, the young branches to-

undersurface which is set in a deeply reticulate secondary and tertiary venation. Also in the long cuspidate leaf acumen, the larger petioles without the 2 glands of $L$. sparsipilis, the brown tomentose pubescence of the inflorescence, and the very small broadly campanulate receptacle.

This species is named in honor of Dr. José Cuatrecasas, who sent the type specimen to me and whose pioneer explorations in Valle still form the basis for most of our knowledge about the plants of that region.

2. Licania fasciculata Prance, $s p$. nov. (Fig. 2)

Licania ab subgenero Moquilea sectio Moquilea pertinens. Ab aliis speciebus inflorescentibus fasciculatis differt. Ab $L$. cabrerae, L. montana, L. durifolia, L. veneralensis foliis parvioribus, nervis primariis impressis, staminis pluribus differt. mentellous, becoming glabrous and prominently lenticellate with age. Leaves with laminas oblong to oblong lanceolate, thickly coriaceous, $9-13.5 \mathrm{~cm}$ long, $2.8-4 \mathrm{~cm}$ broad, acuminate at apex, the acumen $4-7 \mathrm{~mm}$ long, abrupt, cuneate at base, glabrous above, with a compact appressed gray-lanate pubescence beneath; midrib prominulous and tomentellous above, prominent beneath; primary veins $15-19$ pairs, prominent beneath, slightly impressed above; petioles $5-10 \mathrm{~mm}$ long, tomentellous, terete. Stipules $3 \mathrm{~mm}$ long, persistent, membraneous, puberulous, axillary. Inflorescences of short fasciculate racemes $1-2.5 \mathrm{~cm}$ long with flowers densely clustered completely obscuring the rachis. Bracts and oracteoles ovate, tomentellous, subpersistent. Flowers 6-7 $\mathrm{mm}$ long. Receptacle cupuliform, tomentose on exterior, tomentose within. Calyx lobes acute, tomentellous on both surfaces. Petals 5, white, puberulous on exterior. 


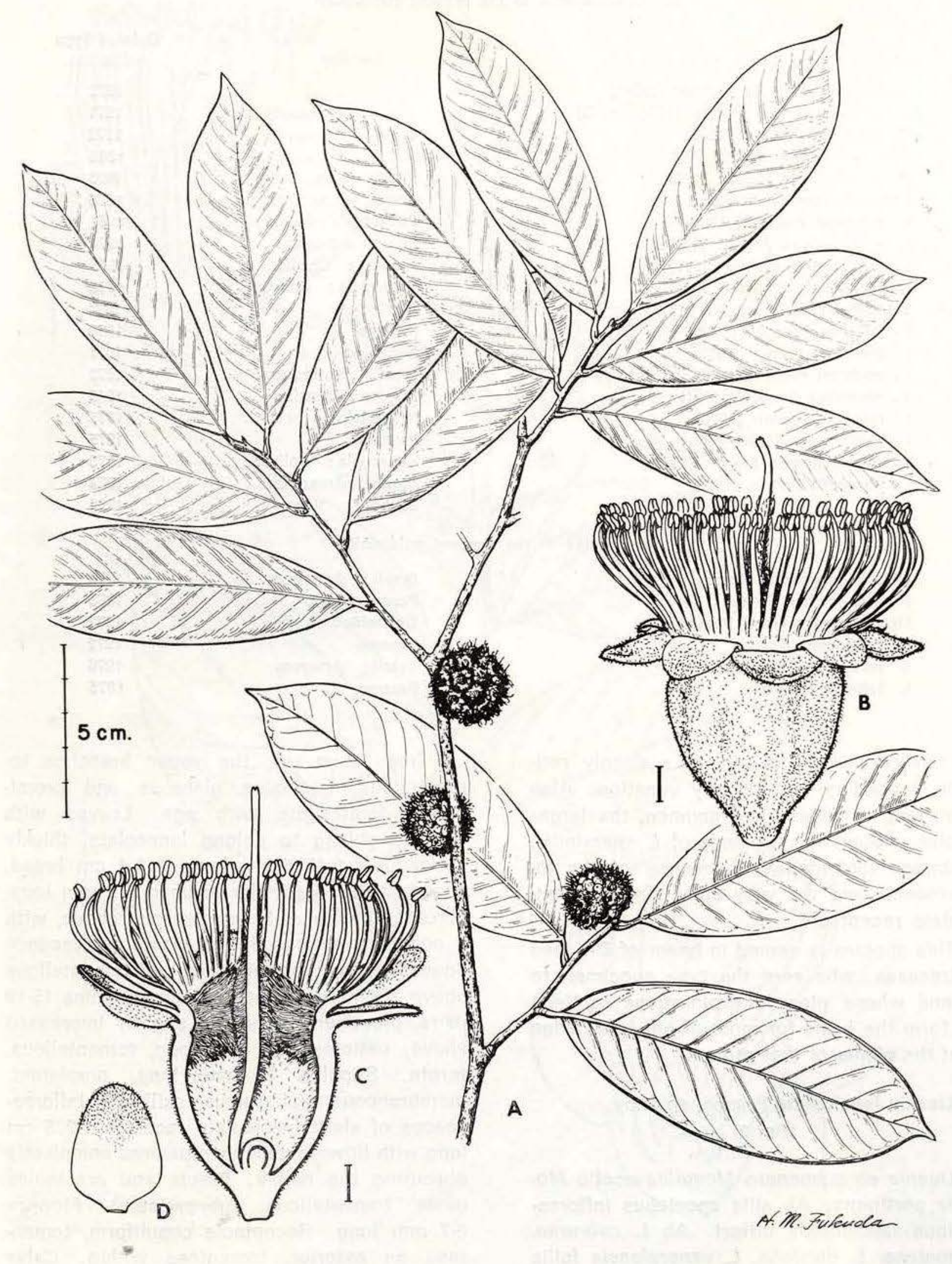

Fig. 2. Licania fasciculata Prance (Correa \& Dressler 1815) : 1, habit; B, flower; C, flowar section; D, petal. 
Stamens ca 60 , inserted in complete circle; filaments far exceeding the calyx lobes, glabrous united at base, the basal fused portion bent inwards, villous. Ovary inserted at base of receptacle, pilose. Style villous for twothirds of length. Fruit not seen.

TYPE. Panama: Zona de Santa Rita, fl. 31 Aug. 1972. M. D. Correa A. \& R. L. Dressler 1815 :(Holotype, MO).

Licania fasciculata belongs to subgenus Moquilea, section Moquilea. It differs from all other species in the section by the fasciculate dense-flowered racemose inflorescence. It is most closely related to the species group of L. maritima, L. cabrerae, L. durifolia, L. monta$n 3, L$. macrocarpa and $L$. veneralensis, having the same pubescence and venation pattern of the $I \in$ af undersurface. It differs in the inflorescence and in the smaller leaves with fewer primary veins which are impressed on the upper surface. L. fasciculata also has a greater number of stames than the other species listed above. It is a most distinct species which is not easily confused with any others in the genus.

Note: another collection by the same collectors probably belongs to Licania fasciculata. Correa et al 1852 from Panama, Camino de Llano a Cartí entre los 14 a 18 kms, de la Carretera a Chepo, $400 \mathrm{~m}$ alt, 20 Feb 1973 $(\mathrm{MO})$. This specimen has young fruit only. The leaves are broader, more oblong with less acute bases than in the type. Further material will be needed to determine the variation in this species and No 1852 is only referred to this species with some hesitancy. The leaf venation, stipules and stem are all very similar to the type of $L$. fasciculata.

3. Licania joseramosii Prance, sp. nov. (Fig. 3)

Licania ab subgenero Moquilea sectio Leptobalanus pertinens. Ab $L$. emarginata et L. calvescens foliis maioribus $13-20 \mathrm{~cm}$ longis, glabris; ramis inflorescentiarum parvis, 1-3 floribus ferentibus; floribus $5 \mathrm{~mm}$ longis; staminibus 19 differt.

Small tree $5 \mathrm{~m}$ tall, the young branches glabrous. Leaves with laminas oblong to oblong-lanceolate, coriaceous, $13-20 \mathrm{~cm}$ long,
$4-6.5 \mathrm{~cm}$ broad, finely acuminate at apex, the acumen $15-20 \mathrm{~mm}$ long, cuneate at base, glabrous on both surfaces; primary veins 9-14 pairs, prominulous on both surfaces; midrib prominent on both surfaces; petioles $4-5 \mathrm{~mm}$ long, rugulose tomentellous when young, terete, with 2 glands near junction with lamina. Stipules linear, ca $6 \mathrm{~mm}$ long, hispidulous, caducous. Inflorescences of panicles with long thick central rachis and short, thin, lateral branches bearing 1-3 flowers, the rachis and branches tomentellous. Flowers $\pm 5 \mathrm{~mm}$ long. Bracts and bracteoles lanceolate, subpersistent, tomentellous on exterior, glabrous within, entire, with long thin acumen, eglandular. Receptacle campanulate, gray tomentose on exterior, tomentose within. Calyx lobes acute tomentose on exterior. Petals absent. Stamens ca 19 inserted around complete circle; filaments slightly exceeding calyx lobes, free to base, glabrous except for pilose annular ring. Ovary inserted at base of receptacle, lanate. Style glabrous, equalling filaments in length. Fruit not seen.

TYPe. Brazil. Amazonas, Manaus-Caracarai road, Km 130, fl 6 Jan 1976 Monteiro \& Ramos 29. (Holotype, INPA 54340; Isotype, NY).

Licania joseramosii belongs to subgenus Moquilea, section Leptobalanus. It is a most distinct species that cannot be easily confused with any other in the genus. It is related to $L$. emarginata and $L$. calvescens but differs in a large number of characters such as the much longer leaves, the larger flowers, the distinctive inflorescence etc. It differs from $L$. emarginata in the greater number of stamens, and from $L$. calvescens in the flowers borne in small groups on secondary inflorescence branches and in the glabrous leaves. Superficially $L$. joseramosii also resemble $L$. longipedicellata in subgenus Moquilea section Moquilea but it differs in the smaller thicker leaves, the much less branched inflorescence, the smaller flowers, and the absence of petals.

This is a second new species of Licania described from material collected in the vicinity of Igarapé Lajes on the Manaus-Caracarai highway where there was a most interesting campina vegetation over a sandstone rock outcrop. The other species Licania ste- 


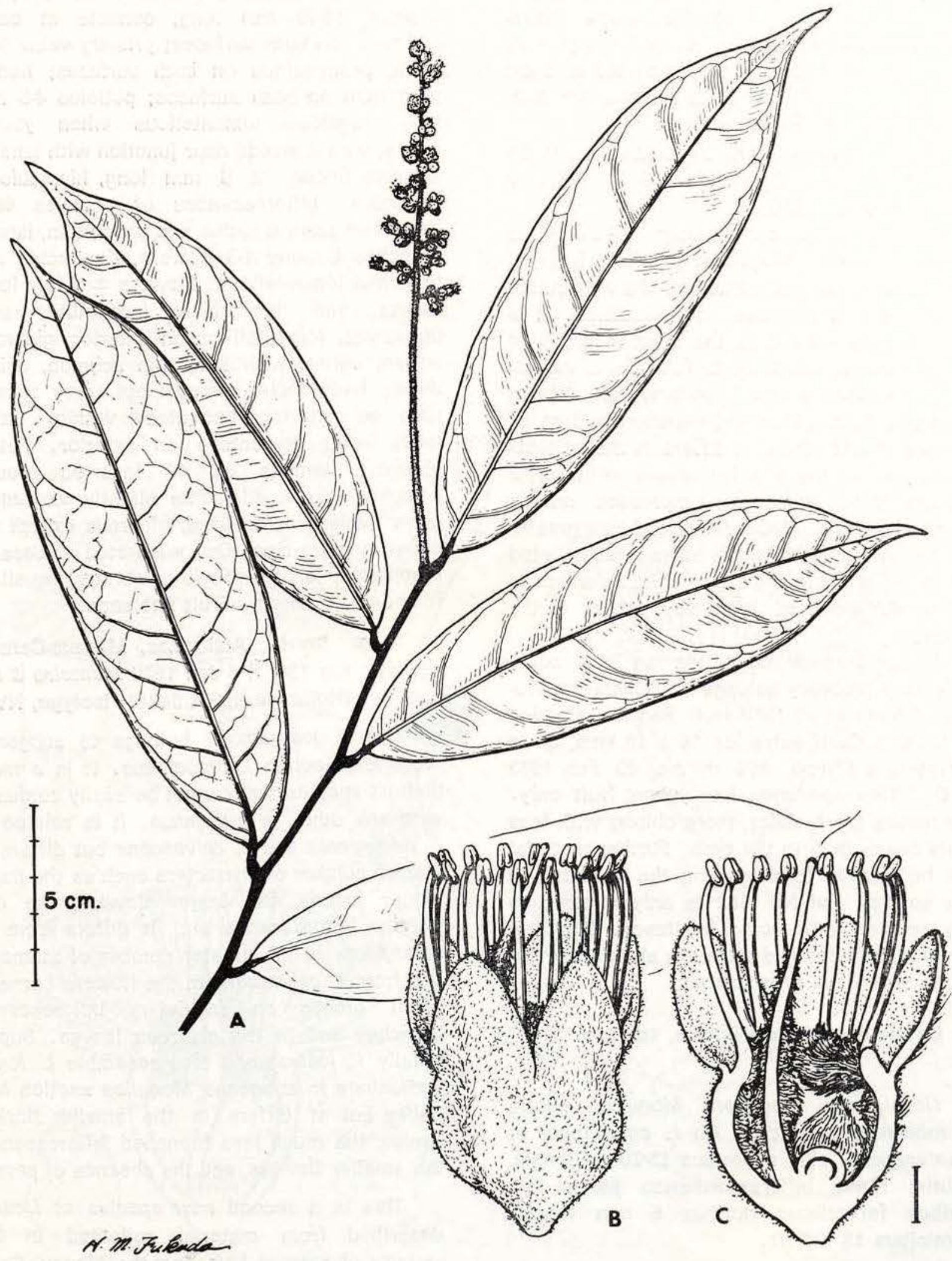

Fig. 3. Licania joseramosii Prance (Monteiro \& Ramos 29): A, habit; B, flower; C, flower section. 
wardii was described in Prance (1976). This habitat which was totally destroyed by colonization in several plant families.

It is a pleasure to dedicate this species in thanks to José F. Ramos who has worked with me as field assistant since 1965 and is one of the collectors of the type specimen.

\section{Licania kallunkii Prance, sp. nov.} (Fig. 4)

Licania ab subgenero Moquilea sectio Moquilea pertinens. Ab L. minutiflora (Sagot) Fritsch inflorescentibus paniculatis floribus in cymulis pluribus 2 vel 3 floribus breviter pedunculatis contractis; foliis parvioribus, apicibus laminarum cuspidatis; stamina 11-12 differt.

Tree $14 \mathrm{~m}$ tall, the young branches very sparsely puberulous soon becoming glabrous, not conspicuousiy lenticellate. Leaves oblong, the laminas coriaceous $5.5-10.5 \mathrm{~cm}$ long, $2.2-4.0 \mathrm{~cm}$ broad, cuspidate at apex, the acumen $6-10 \mathrm{~mm}$ long, subcuneate at base; glabrous on both surfaces; midrib plane above, prominent beneath, glabrous, primary veins 9-12 pairs almost plane and inconspicuous on both surfaces, glabrous; petioles $6-7 \mathrm{~mm}$ long, glabrous, canaliculate, eglandular. Stipules small, lanceolate, puberulous, caducous. Inflorescences terminal and axillary panicles 5-11 $\mathrm{cm}$ long, 3 branched, the rachis and branches sparsely gray puberulous. Flowers $2.5-3 \mathrm{~mm}$ long, borne in few-flowered (2-3) cymules attached to primary branches by short secondary branches or peduncles . Bracts and bracteoles very early caducous (not seen). Receptacle campanulate, gray puberulous on exterior, tomentose within; pedicels ca $1 \mathrm{~mm}$ long, gray puberulous. Calyx lobes acute gray puberulous on both surfaces. Petals 5 , white . Stamens 11-12, inserted in a complete circle; filaments exceeding calyx-lobes, free to base. Ovary inserted at base of receptacle, almost glabrous with only a few hairs. Style lanate on lower portion, equalling filaments in length. Fruit not seen.

TYPE: Panama: Colon, Santa Rita Road, $17 \overline{\mathrm{km}}$ from Boyd-Roosevelt Highway, $450 \mathrm{~m}$ alt., fl. 14 Mar 1975. S. Mori \& J. Kallunki 5052 (Holotype, NY; Isotype, MO).

\section{HABITAT: Wet forest.}

Licania kallunkii belongs to subgenus Moquilea section Moquilea. It is most closely related to $L$. minutiflora (Sagot) Fritsch a species of the Guianas and Northern Amazonia, but it differs in the inflorescence where the flowers are borne in small groups on short tertiary inflorescence branches, in the smaller leaves, with a more cuspidate acumen, and in the fewer stamens. Since L. kallunkii has only 12 stamens it has fewer than any other species of the section, but its exserted stamens and presence of petals as well as its similarity to L. minutiflora all place it in section Moquilea. It differs from another related and recently described species from Panama in the same section, L. chiriquiensis Prance (1977), in many characters including the smaller flowers with a gray puberulous not yellow tomentellous indumentum and the spreading much longer inflorescences, the thinner chartaceous leaves with a more cuspidate attenuate apex etc.

This species is named for one of the collectors Ms. Jackie Kallunki whrse collections with S. Mori in Panama have discovered many novelties.

\section{Licania guatemalensis Lundeel Wrightia $5(2): 39.1974$.}

Tree ca $30 \mathrm{~m}$, the young branches glabrous. Leaves with laminas broadly elliptic, $10-21 \mathrm{~cm}$ long, $5.5-9.5 \mathrm{~cm}$ broad, apex with short acumen 4-7 $\mathrm{mm}$ long, base rounded to subcuneate, glabrous on both surfaces; primary veins 8-10 pairs, prominulous on both surfaces, secondary venation prominulous and conspicuously reticulate on both surfaces; midrib prominulous and flattened on both surfaces, glabrous; petioles $3-5 \mathrm{~mm}$ long, slightly canaliculate, glabrous. Stipules small, triangular, axillary. Inflorescences terminal panicles to 13 $\mathrm{cm}$ long, the flowers borne in small groups on short secondary branches, the rachis puberulous soon glabrescent, the branches gray tomentellous. Flowers ca $2.5 \mathrm{~mm}$ long. Bracts and bracteoles small, ovate, persistent, tomentellous. Receptacle campanulate, tomentellous on exterior, tomentose within. Calyx lobes small, to $1 \mathrm{~mm}$ long, triangular, tomentellous on exterior, puberulous within. Petals 5, white, tomentellous on exterior, 


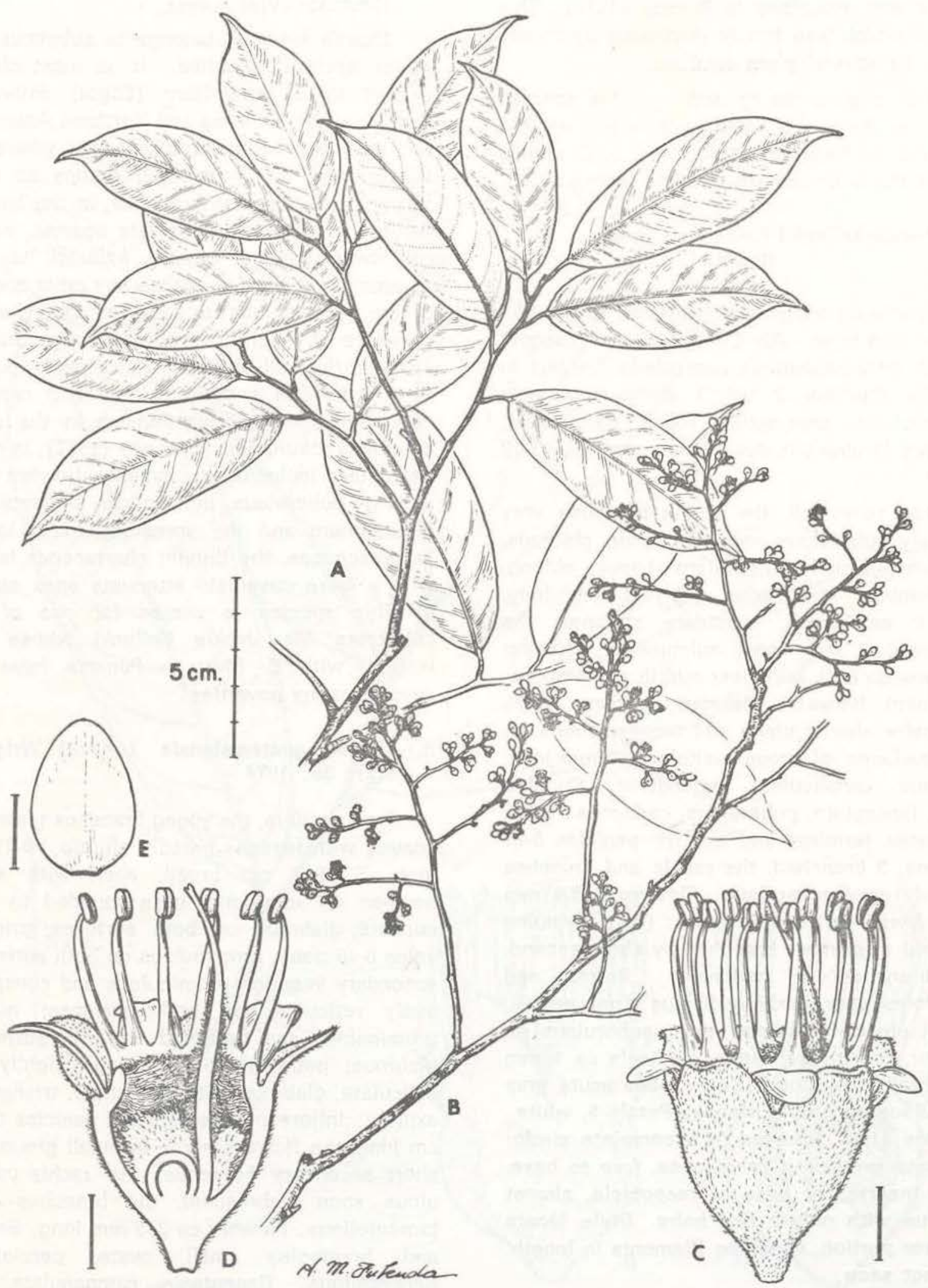

Fig. 4. Licania kallunkii Prance (Mori \& Kallunki 5052) : A, habit; B, inflorescence; C, flower; D, flowet section: $E$, petal. 
sticking together and dehiscing in a calyptralike mass, $1.2 \mathrm{~mm}$ long. Stamens 13-15, inserted in a complete circle, filaments far exceeding calyx-lobes, free to base, glabrous. Ovary inserted at base of receptacle, tomentose on exterior. Style glabrous. Fruit not seen.

TYPE. Contreras 10742, Guatemala, Dept9 Izabel, between Seja and Fronteras on PetenGuatemala road, fl (Holotype, LL; Isotype, US).

Distribution. Known only from the type gathering from high forest. Flowering in May.

Licania guatemalensis belongs to subgenus Moquilea section Moquilea and is quite distinct and not easily confused with any other species in the section. The leaves appear quite different in their venation and flattened midribs with short, thick petioles. It is probably closest to L. kallunki Prance from Panama, but differs in the much longer leaves with abrupt acumen, the shorter, thicker petioles, the smaller petals, the glabrous style etc.

6. Licania mexicana Lundell, Wrightia 5(2) : 40. 1974 .

Tree $10 \mathrm{~m}$ tall, the young branches lanate to puberulous and soon glabrous. Leaves with laminas narrowly oblong to lanceolate, coriaceous, $6.5-13 \mathrm{~cm}$ long, $2.5-4 \mathrm{~cm}$ broad, gradually attenuate to acute apex, coneate at base, glabrous above, with a soon caducous lanate pubescence beneath when young only; midrib prominulous above, prominent beneath; primary veeins $6-8$ pairs, prominulous on both surfaces, secondary venation prominulous and conspicuously reticulate on both surfaces; petioles 1.5-3.5 mm long, rugose, terete, lanate when very young soon becoming glabrous. Stipules triangular, persistent, $2 \mathrm{~mm}$ long, axillary, lanate when young. Inflorescence of terminal panicles $2-3.5 \mathrm{~cm}$ long, with short primary branches (2 old inflorescences only seen) gray-brown the rachis and branches tomentellous. Bracts and bracteoles small, ca $1 \mathrm{~mm}$ long, persistent, tomentellous, ovate-triangular. Receptacle campanulate, tomentellous on exterior, pilose within. Calyx lobes triangular, $1 \mathrm{~mm}$ long, acute, reflexed, tomentellous. Petals? (not seen in old flowers present).
Stamens 14-15, inserted around complete circle; exserted beyond calyx lobes; the filaments glabrous, united at base $1.5 \mathrm{~mm}$. Ovary glabrous, inserted at base of receptacle. Style glabrous.

Type. C.L. Lundell 13023, Mexico, Sinaloa, between Rancho Del Piño and Chele, fl 11 May, 1943 (Holotype, LL; Isotype, MICH).

Distribution. This species is known only from the type.

Licania mexicana was described from poor material with only old flowers present, and is thus difficult to relate to other species. It belongs to subgenus Moquilea either to section Moquilea or section Leptobalanus, depending on the presence or absence of petals which cannot be observed in the old flowers. It probably belongs to section Leptobalanus and seems to be most closely related to the Central American species $L$. sparsipilis Blake. It differs in the inflorescence, the less acuminate leaves with shorter petioles and the greater number of stamens.

\section{Hirtella Linnaeus}

1. Hirtella magnifolia Prance, sp. nov. (Fig. 5)

Ab. H. elongata Mart. \& Zucc. foliis maioribus, $18-40 \mathrm{~cm}$ longis, $8-16 \mathrm{~cm}$ latis; nervis primariis $14-18$ jugis, petiolis longioribus $5-9$ $\mathrm{mm}$ longis, latioribus $3.5-6 \mathrm{~mm}$ latis; basibus laminarum cum glandibus duobus munitis; inflorescentibus rufo-tomentellis differt.

Tree to $10 \mathrm{~m}$ tall, the young branches shortly tomentellous becoming glabrous and conspicuously lenticellate with age. Leaves oblong-elliptic, chartaceous, $18-40 \mathrm{~cm}$ long, 8-16 $\mathrm{cm}$ broad, abruptly acuminate at apex, the acumen $7-13 \mathrm{~mm}$ long, curved, the base rounded; glabrous above, with a few stiff appressed hairs beneath on venation; with 2 glands at junction of upper surface of lamina and the petioles; primary veins $14-18$ pairs prominent beneath, prominulous above; midrib prominent beneath, prominulous above, tomentellous on both surfaces; petioles $5-9 \mathrm{~mm}$ long, 3.5-6 mm thick, tomentellous, eglandular, terete. Stipules early caducous (not seen). 


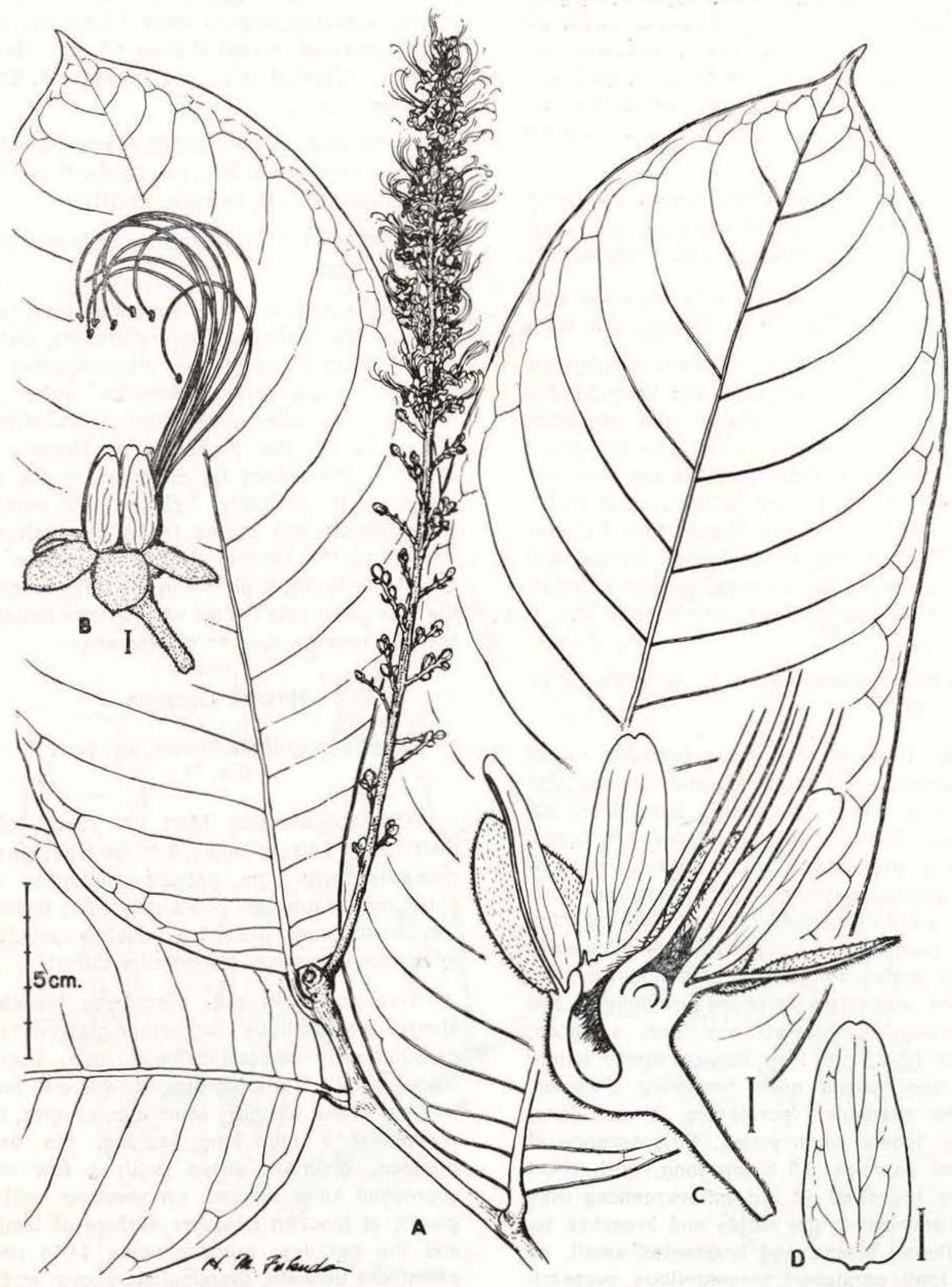

Fig. 5. Hirtella magnifolia Prance (Lleras et al. P17216 1815).: A, habit B, flower; C, flower section; 'D, petal. 
Inflorescences terminal panicles with a long central rachis $12-18 \mathrm{~cm}$ long and many short few-flowered lateral primary branches, the rachis and branches rufous tomentellous. Bracts and bracteoles ovate, persistent, graybrown tomentellous on both surfaces, eglandular. Flowers 5-6 mm long. Receptacle campanulate, tomentellous on exterior, glabrous within except for sparsely pilose area around throat. Calyx lobes acute, gray tomentellous on both surfaces. Petals, 5 white, glabrous. Stamens 5-7, unilateral with toothed portion of ring opposite to them, filaments far exceeding calyx lobes, glabrous. Style glabrous. Ovary inserted at mouth of receptacle, pilose. Fruit not seen.

TYPE: Brazil, Amazonas, Rio Javari, Estirão do Equador, flowering 21 Oct, 1976, G.T. Prance, R. J. Hill, T. D. Pennington \& J. Ramos 23974 (Holotype INPA; Isotypes, FHO, MO, NY, MG, US) .

Additional material: Brazll, Amazonas, Rio Javari, Estirão do Equador, flowering 2 Aug, 1973. E. Lleras et al P17216 (INPA, NY).

HABITAT: Upland forest on terra firme, understory in open clearings.

Hirtella magnifolia has the largest leaves of any described species of the genus, often attaining $40 \mathrm{~cm}$ in length on the fertile branches. It is most closely related to $H$. elongata Mart. \& Zucc., and H. eriandra Benth. It differs from both species in the larger leaves with a greater number of primary veins. It also differs from $H$. elongata in the rufous tomentellous pubescence of the inflorescence, the 2 glands at the junction of the upper surface of the leaf lamina and petioles; the rounded not subcordate leaf bases; the longer inflorescence branches. It differs from $\mathrm{H}$. eriandra in the inflorescence branching and the lamina glands.

The flowers of the type tree of this species were much visited by butterflies at the time of collection, and like some other species of Hirtella, H. magnifolia is probably butterfly pollinated.
2. Hirtella revillae Prance, sp. nov. (Fig. 6)

Hirtella ab sectio Myrmecophila pertinens abaliis speciebus pedicellis longioribus 8-15 $\mathrm{mm}$ longis, hirsutis, floribus dense brunneohirsutis differt.

Trees $8 \mathrm{~m}$ tall; the young branches hispid. Leaves with laminas chartaceous-membranaceous, oblong, $19-22 \mathrm{~cm}$ long, $8-10 \mathrm{~cm}$ broad, abruptly acuminate at apex, the acumen 7-10 $\mathrm{mm}$ long, rounded at base and bearing 2 swollen ant cavities, hirsute on venation beneath with sparse appressed hairs on upper surface; midrib prominent beneath prominulous above, hirsute on both surfaces; primary veins 13-17 pairs prominent beneath, prominulous above. Stipules linear, persistent, hispid. Inflorescences of axillary racemes $5-6 \mathrm{~cm}$ long, the rachis light brown hispid, the lower pedicels longer than the upper ones giving a slightly corymbose appearance. Bracts and bracteoles linear, persistent, hispid. Flowers 8-10 $\mathrm{mm}$ long (excluding pedicels). Receptacle campanulate, light brown hispid on exterior, glabrous within even at throat except around base of uvary; pedicels $8-15 \mathrm{~mm}$ long. Calyx lobes lanceolate, hispid on exterior. Petals 5, white, glabrous. Stamens 6 , the filaments far exceeding calyx lobes. Style hirsute on lower portion only. Ovary inserted at mouth of receptacle, glabrous except around base. Fruit not seen.

TYPE: Peru: Loreto, Maynas, Rio Nanay $4 \mathrm{~km}$ from Michana, $150 \mathrm{~m}$ alt., $\mathrm{fl} 10$ Jan 1975, A. Gentry, F. Ayala \& J. Revilla 15807 (Holotype, NY; Isotype, MO).

HAвттAт: Upland forest on white sand, poorly drained, swampy.

Hirtella revillae belongs to the section Myrmecophila which previously contained 6 species. It has the swollen ant cavities at the base of the leaves, and the hispid pubescence characteristic of all members of this section. It differs in the very long pedicels and in the distinctive dense hirsute pubescence of the pedicels and flowers, and the glabrous ovary and mouth of the receptacle, anc is most closely related to $H$. physophora Mart. \& Zucc. 


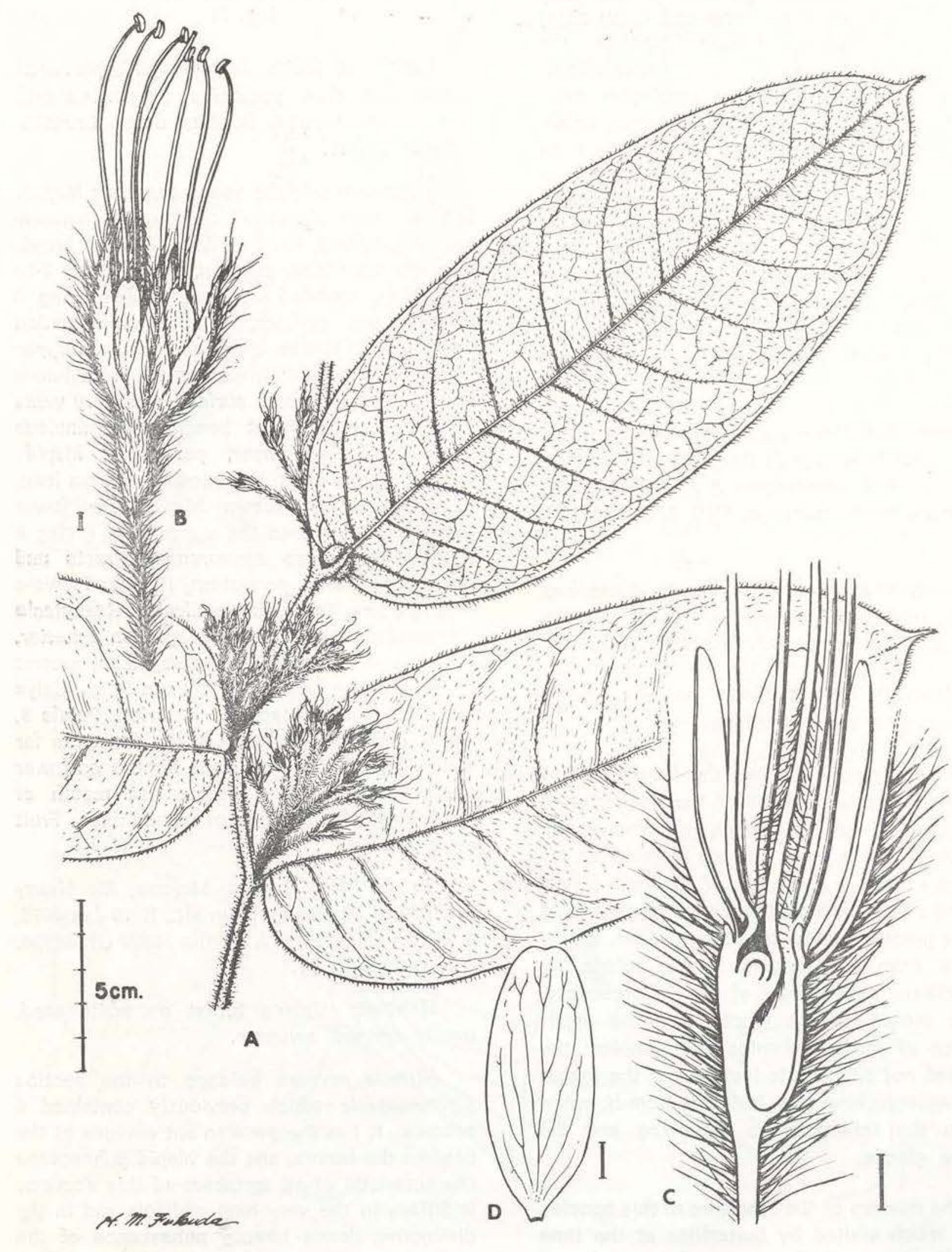

Fig. 6. Hirtella revillae (Gentry et al. 15807): A, habitat; B, flower; C, flower section; D, petal. 
The inflorescence is of rather intermediate length in comparison to other species of section Myrmecophila which either have much more compact fasciculate inflorescences or elongate racemes or panicles. Only $\mathrm{H}$. duckei has racemose inflorescences as short as $H$. revillae but $H$. duckei differs in many other ways.

This species is named for one of the collectors Juan Revilla of the Flora of Peru Project, one of the promising young collectors of Amazonian Peru.

\section{Hirtella tubiflora Cuatr.}

This species was known only from the type collection from the coastal lowlands of Valle in Colombia at $30-50 \mathrm{~m}$ altitude, in the Rio Calima region. Recently two new collection have ben made from the wet forests of Panama at about $800 \mathrm{~m}$ altitude.

Panama. Panama Prov. Cerro Jefe, J. T. \& F. Witherspoon $8543 \mathrm{fl}(\mathrm{MO}, \mathrm{NY})$. Veraguas, 3-4 km W of Sarita Fe, $2500 \mathrm{ft}$ alt, M. Nee 11288 $\mathrm{fl}(\mathrm{MO}, \mathrm{NY})$.

\section{ACKNOWLEDGEMENTS}

Field work in Amazonia was supported by National Science Foundation grant INT ...... 75-19282. I am grateful to the Instituto Nacional de Pesquisas da Amazônia for collaboration and especially to Drs. João Murça Pires and William A. Rodrigues.

\section{Resumo}

Quatro novas espécies do gênero Licania e duas de Hirtella (Chrysobalanaceae) sāo descritas. Todas as espécies são baseadas em material coletado após a publicaçäo da monografia da família Chrysobalanaceae em 1972. Três delas são da Amazônia, duas de Panamá e uma da regiảo Pacífica da Colômbia. Este fato vem confirmar que estas áreas ainda são pouco estudadas e necessitam de mais pesquisas. Notas sobre três espécies pouco conhecidas são também apresentadas.

\section{LITERATURE CITED}

LUNDELL, C. L.

1974 - Studies of American plants. VI: Rosaceae. Wrightia, 5(2) : $39-40$.

PRANCE, G. T.

1972 - Monograph of Chrysobalanaceae. Flora Neotropica, 9:1-406.

1973 - New and Interesting Chrysobalanaceae from Amazonia, Acta Amazonica, 2(1): 7-16.

$1974 a$ - Supplementary studies of American Chrysobalanaceae 3. Acta Amazonica, 4(1) : 17-23.

1974b- A new Peruvian species of chiropterophilous Couepia (Chrysobalanaceae) Brittonia, 26. 302-304. 26 : 302-304.

1976 - Additions to Neotropical Chrysobalanaceae. Brittonia, 28 : 209-230.

1977 - Two new species for the Flora of Panama. Brittonia, 29 : 154-158.

1978 - In : Berlin, B. \& Prance, G. T. - Insect Galls and human Ornamentation: The Ethnobotanical significance of a New Species of Licania from Amazonas, Peru. Biotropica, 10.

(Aceito para publicação em 27/06/78) 